\title{
THE OPEN BUSINESS MODEL IN A DYNAMIC BUSINESS ENVIRONMENT: A LITERATURE REVIEW
}

\author{
M. Khumalo ${ }^{1 *}$ \& E. van der Lingen ${ }^{1}$
}

\section{ARTICLE INFO}

\section{Article details}

Presented at the $28^{\text {th }}$ annual conference of the Southern African Institute for Industrial Engineering (SAIIE), held from 25-27 October 2017 in Vanderbijlpark, South Africa

Available online $\quad 22$ Nov 2017

\section{Contact details}

Corresponding author u15402542@tuks.co.za

Author affiliations

1 Department of Engineering and Technology Management, Graduate School of Technology Management, University of Pretoria, South Africa

\# $\quad$ Author was enrolled for a PhD (Technology and Innovation Management) in the Department of Engineering and Technology Management, University of Pretoria

DOI

http://dx.doi.org/10.7166/28-3-1851
ABSTRACT

The open business model is the integration of open innovation with a business model. It is an important bridging construct between innovation and organisational performance in public and private organisation environments. The open business model is characterised by consistent change in the pursuit of competitiveness. Organisations' inability to navigate environmental changes and challenges successfully, or their complacency about doing so, are major issues that have proved costly or lifethreatening for many firms. Organisations constantly face two issues: competitiveness, and changes in the business environment. The literature points to numerous contentions about the open business model construct, about which the professional and academic fraternities have not yet reached a conclusion. Interestingly, there is near-homogeneity in the findings that business models are naturally stable and that, therefore, the open business model requires conscious effort and ingenuity to adopt. The open business model is a rising construct of public and private organisation environments, arousing interest and raising a plethora of questions from multiple groups.

\section{OPSOMMING}

Die oop sakemodel is die integrasie van oop innovasie en 'n sakemodel. Dit is 'n belangrike oorbrugsvoorstelling tussen innovasie en organisatoriese prestasie in openbare en privaat organisasie-omgewings. Die oop sakemodel word gekenmerk deur konstante verandering in die strewe na mededingendheid. Organisasies se onvermoë om omgewingsveranderings en -uitdagings suksesvol te hanteer en/of hul met oorgawe uit te voer, is belangrike kwessies wat vir baie maatskappye duur of lewensbedreigend is. Organisasies moet voortdurend oor twee sake besin: mededingendheid en veranderinge in die besigheidsomgewing. Die literatuur dui op talle stellings rondom die oop sakemodel-konstruksie. Die professionele en akademiese groepe het nog nie 'n finale gevolgtrekking bereik nie. Interessant genoeg is daar redelike ooreenkoms tussen die bevindings dat sakemodelle natuurlik stabiel is, en daarom vereis die oop sakemodel bewuste moeite en vindingrykheid om dit aan te neem. Die oop sakemodel wek egter baie belangstelling by openbare en private organisasies, en het 'n oorvloed vrae uit verskeie groepe tot gevolg.

South Africa considers innovation to be an important catalyst in the economy, and National Treasury has budgeted R13.6 billion over the medium term [1], with R1 billion set aside in 2018/19 for innovation-oriented activities [2]. This is predominantly distributed through public sector-driven initiatives, some of which are partner-oriented. The extensive participation in in-licensing - for example, in enterprise resource planning (ERP) systems such as the Systems, Applications and Products (SAP) suite, and numerous public-private partnerships such as the Cisco Networking 
Academy - is only one of the many tools with which public sector organisations have harnessed and created value from open innovation.

Research still struggles to provide a unified and generally accepted definition of the open business model concept [3]. Different domains, therefore, have used and developed the concept independently in silos [4]. Based on the definition of the business model proposed by A. Osterwalder\&Y. Pigneur [5], the open business model in this study is defined as a construct that transcends organisational boundaries and defines the rationale of how that organisation creates, delivers, and captures value. We posit that the open business model still seeks to achieve the same objectives as the business model, although external parties are explicitly involved. These parties are collectively referred to as the business ecosystem.

Research on open business models is still very new, and researchers have primarily focused on the benefits of open business models [6-8], developing typologies [9-11], identifying challenges associated with implementing open business models [12], and the link to performance [13]. However, despite the undoubted relevance of openness and collaboration in today's networked economy, the majority of existing business model research is firm-centric $[14,15]$ and the aspects and effects of openness are not sufficiently understood [11].

\section{METHODOLOGY}

In this study, a systematic literature review has been employed because it is replicable and transparent [16]. It is also unbiased and comprehensive [17], trustworthy, rigorous and auditable [18], and provides a coherent overview [19]. The systematic literature review also gives a theoretical grounding for envisaged further exploration, and allows the development of a framework or model.

\subsection{Search strategy}

Three databases - the ISI Web of Science, EBSCOhost, and Scopus - were chosen for the literature search. The ISI Web of Science's Social Sciences Citation Index ( $\mathrm{SSCl}$ ) database was chosen due to its status as one of the most comprehensive databases of peer-reviewed journals in the social sciences [20]. Furthermore, it is known to employ strict inclusion evaluation processes [21]. The EBSCOhost database was chosen because it is among the largest and most comprehensive databases for business-oriented scholarly full-text journals compared with other popular databases [22]. Scopus was chosen due to its immense popularity alongside the ISI Web of Science, with some studies, such as that of Falagas, Pitsouni, Malietzis and Pappas [e.g. 23] rating it the largest searchable citation and abstract source for literature. Scopus and the ISI Web of Science are two of the most extensive databases [24].

Questions around Google Scholar's transparency, precision, consistency, and completeness as a scientific resource informed the choice to use it as a supplement for retrieval rather than as a primary literature source $[25,26]$.

Following in the footsteps of S. Schneider\&P. Spieth [27], we adopted the three-stage process for systematic literature reviews suggested by D. Tranfield, D. Denyer\&P. Smart [28]. We identified our research objective and then designed our literature review process. This was followed by the review process itself, and a report on the review.

\subsection{Study selection}

The first phase of the electronic database search selected articles that were published between 2002 and April 2017. The search used the key phrases 'open innovation', 'business model', and 'open business model'. The second phase eliminated articles that did not meet the inclusion criteria, such as the key phrase, the category or domain area of the study, and the publication and document type. It was critical that each article be vetted against relevant inclusion criteria in order to maintain the validity and reliability of the review [29]. Further elimination was based on the methodological screening template (see Table 1). These selection criteria were similar to criteria followed by $L$. Pittaway, M. Robertson, K. Munir, D. Denyer\&A. Neely [30]. 
Table 1: Criteria for methodological screening

\begin{tabular}{|c|l|}
\hline Symbol & Definition of criteria \\
\hline A & Type of literature limited to academic, therefore peer-reviewed, sources. \\
\hline B & $\begin{array}{l}\text { Topic/field of study should be in, or resonate with, management and information communication } \\
\text { technology or relate to, or inform, part or all of its affiliated or related fields. }\end{array}$ \\
\hline$Y$ & $\begin{array}{l}\text { Studies with no (0) citations over at least three years in a research area reasonably well-covered } \\
\text { in existing literature. }\end{array}$ \\
\hline$\delta$ & $\begin{array}{l}\text { Results limited to the top five publications and journals relevant to the field of management, } \\
\text { technology, innovation, and their related fields; order determined by hit count. }\end{array}$ \\
\hline$\varepsilon$ & $\begin{array}{l}\text { Studies relating to management, technology, innovation, and organisational strategy, culture, or } \\
\text { change. }\end{array}$ \\
\hline
\end{tabular}

One assumption of citation analysis is that authors cite their influences; so citations serve as surrogates for the influence of the cited work [31]. Our elimination of papers with no citation (criterion $\gamma$ ) over three years is based on this understanding, with the interpretation that such papers have yet to influence the research field.

\section{THEORETICAL BACKGROUND}

We conducted a review of the open business model construct and expanded it to include the basic constructs of a business model and open innovation to achieve completeness and finality. Our understanding of the open business model, as defined above, follows the work of $\mathrm{H}$. Chesbrough [32]. Furthermore, the components of open innovation and the business model ultimately define the components of the open business model. Thus the study and comprehension of these concepts are critical. An alternative view of the open business model's conception is also offered.

Figure 1 is a simplified depiction of our understanding of the open business model.

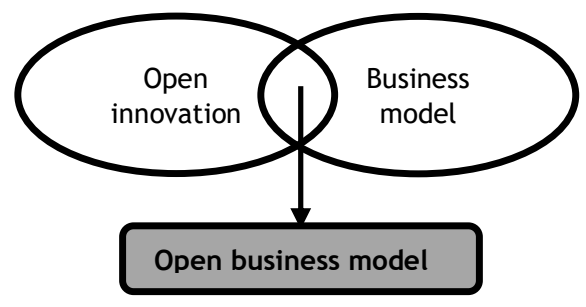

Figure 1: Conception of the open business model

\subsection{Open innovation}

Open innovation is best understood from the original definition as a paradigm that assumes that organisations can and should use external and internal ideas, as well as internal and external paths to market, as they look to advance their technology [33]. The well-documented cases of open innovation champions in the USA, such as IBM and Procter and Gamble, have helped to catapult growing worldwide interest in this paradigm [34] (see Figure 2).

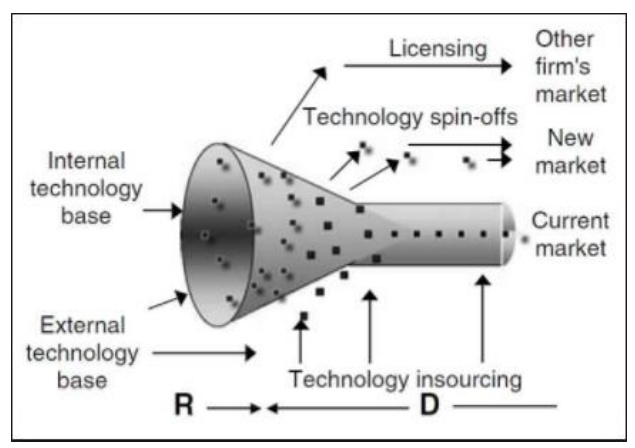

Figure 2: The open innovation model [35] 
Questions about the practice and governance of open innovation have been inevitable. One of these concerns the literal or contextual use of the word 'open'. Table 2 depicts open innovation practices as inbound or outbound, which denotes the direction of knowledge flow. Chesbrough [36] defines outside-in (or inbound) as knowledge sourced from outside the organisation for internal application, and inside-out (or outbound) as knowledge produced internally and released for external application.

Table 2: Open innovation practices

\begin{tabular}{|c|c|}
\hline Open innovation practice & Author(s) \\
\hline \multicolumn{2}{|r|}{ Inbound } \\
\hline Alliances & $\begin{array}{l}\text { M. Bianchi, A. Cavaliere, D. Chiaroni, F. Frattini\&V. Chiesa } \\
\text { [37], E. Enkel, O. Gassmann\&H. Chesbrough [38] }\end{array}$ \\
\hline Purchase of scientific services & $\begin{array}{l}\text { M. Bianchi, A. Cavaliere, D. Chiaroni, F. Frattini\&V. Chiesa } \\
\text { [37], D. Chiaroni, V. Chiesa\&F. Frattini [39] }\end{array}$ \\
\hline In-licensing & $\begin{array}{l}\text { M. Bianchi, A. Cavaliere, D. Chiaroni, F. Frattini\&V. Chiesa } \\
\text { [37], K.-H. Tsai\&J.-C. Wang [40], O. Gassmann [41], A.L.D.A. } \\
\text { Burcharth, M.P. Knudsen\&H.A. Søndergaard [42] }\end{array}$ \\
\hline Institutional collaboration & K. Laursen\&A. Salter [43] \\
\hline Venture capital & D. Benson\&R.H. Ziedonis [44] \\
\hline Acquisition & $\begin{array}{l}\text { W. Vanhaverbeke, I. Vermeersch\&S. De Zutter [45], T. } \\
\text { Holzmann, K. Sailer\&B.R. Katzy [46] }\end{array}$ \\
\hline Customer involvement & $\begin{array}{l}\text { A. Spithoven, B. Clarysse\&M. Knockaert [47], V. Van de } \\
\text { Vrande, J.P.J. de Jong, W. Vanhaverbeke\&M. de Rochemont } \\
\text { [48] }\end{array}$ \\
\hline $\begin{array}{l}\text { External networking (including } \\
\text { conferences, fairs, knowledge clusters, } \\
\text { crowdsourcing) }\end{array}$ & $\begin{array}{l}\text { O. Gassmann [41], H. Van Der Meer [49], P.E. Harland\&A. -M. } \\
\text { Nienaber [50] }\end{array}$ \\
\hline \multicolumn{2}{|r|}{ Outbound } \\
\hline Spinoff & $\begin{array}{l}\text { H. Chesbrough\&R.S. Rosenbloom [51], H. Chesbrough\&S. } \\
\text { Brunswicker [52] }\end{array}$ \\
\hline Supply of scientific services & $\begin{array}{l}\text { M. Bianchi, A. Cavaliere, D. Chiaroni, F. Frattini\&V. Chiesa } \\
\text { [37], D. Chiaroni, V. Chiesa\&F. Frattini [39] }\end{array}$ \\
\hline Out-licensing & $\begin{array}{l}\text { M. Bianchi, A. Cavaliere, D. Chiaroni, F. Frattini\&V. Chiesa } \\
\text { [37], U. Lichtenthaler\&H. Ernst [53], U. Lichtenthaler\&H. } \\
\text { Ernst [54] }\end{array}$ \\
\hline External technology commercialisation & U. Lichtenthaler\&H. Ernst [53] \\
\hline Knowledge exploitation & $\begin{array}{l}\text { A.L.D.A. Burcharth, M.P. Knudsen\&H.A. Søndergaard [42], V. } \\
\text { Van de Vrande, J.P.J. de Jong, W. Vanhaverbeke\&M. de } \\
\text { Rochemont [48], P. Wynarczyk, P. Piperopoulos\&M. McAdam } \\
\text { [55] }\end{array}$ \\
\hline Venturing out & H. Van Der Meer [49], H. Chesbrough\&S. Brunswicker [52] \\
\hline Industry groups & H. Van Der Meer [49] \\
\hline Institutional collaboration/partnerships & H. Van Der Meer [49] \\
\hline
\end{tabular}

Some authors, such as Gassmann, Enkel and Chesbrough [e.g. 56], provide empirical evidence of large, well-known companies such as IBM, BASF, and BMW exhibiting different practices and degrees of openness. P. Trott\&D. Hartmann [57] and L. Dahlander\&D.M. Gann [58] noted criticism of the open innovation concept for constructing what they consider to be an artificial dichotomy between closed and open approaches. Exploring different degrees and types of openness in a continuum, such as the open business model, seems to provide an interesting direction for open innovation investigations [59]. 


\subsection{Business model}

While various authors have studied the business model construct, which provides valuable insights, there is currently no consensus about definitions and conceptual boundaries [60]. There are broad understandings of the business model, such as "framework for making money" [61], a "blueprint for how to run a business" [5], and "the logic of the firm, the way it operates and how it creates value for its customers" [62]. More comprehensive definitions are available in the literature. We prefer the ones of C. Baden-Fuller\&M.S. Morgan [63], who describe how a firm organises itself to create and distribute value in a profitable manner, and A. Osterwalder\&Y. Pigneur [5], who describe the rationale of how an organisation creates, delivers, and captures value. The business model of $A$. Osterwalder\&Y. Pigneur [5] became the business model canvas (BMC) (see Figure 3). This is used by various large organisations, small and medium enterprises (SMEs), and potential entrepreneurs.

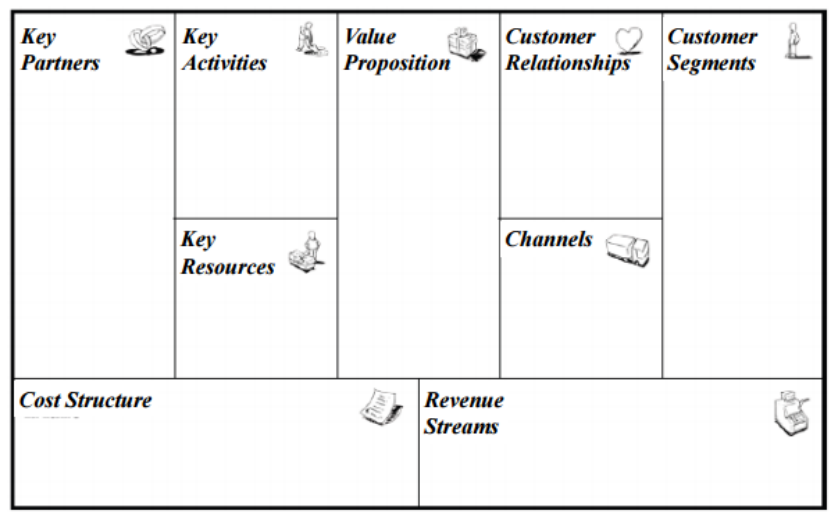

Figure 3: The business model canvas [5]

B.W. Wirtz, A. Pistoia, S. Ullrich\&V. Göttel [64] summarise previous definitions for business models by regarding the purpose of a business model's contents as leading to keeping the promise of service, the satisfaction of needs and profitability, and providing the assurance of a long-term competitive advantage. A deeper understanding of the purpose of the business model can be achieved by focusing on the elements. The BMC, arguably the most popular business model framework, was applied as the benchmark for comparing the business model elements mentioned in various sources (see Table $3)$.

\subsection{Open business model conception - an alternative view}

One stream in the literature, represented by Davey, Brennan, Meenan and McAdam [e.g. 7, 73, 74], and others, closely links the open business model to openness about an organisation's research and development activities in relation to the open innovation paradigm defined by H.W. Chesbrough [33]. This view subscribes to the centrality of open innovation in the open business model construct. The other stream does not necessarily see the open business model as requiring openness and collaboration to reside in (open) innovation activities [e.g. 11, 12, 75]. The scholars in the latter stream reiterate that the "openness to innovations and the openness of business models need to be adequately recognised, understood and treated as separate phenomena" [11].

M. Heikkila\&J. Heikkila [76] noted that this difference appeared markedly between American and European scholars. The American school of thought mainly concentrated on classifying and using business models in a context of open innovation [77, 78], while the European school has focused more on the ontologies and design methodologies of business models [5, 79]. Proponents of the former have had a larger share of coverage in the literature than the latter, for whom (including Weiblen [e.g. 80]) the alternative view of an open business model is more attractive. 
Table 3: Matching business model elements in the literature against the business model canvas

\begin{tabular}{|c|c|c|c|c|c|c|c|c|c|}
\hline & \multicolumn{9}{|c|}{ Business model elements } \\
\hline $\begin{array}{r}\text { BMC } \\
\text { elements }\end{array}$ & $\begin{array}{l}\text { Customer } \\
\text { segments }\end{array}$ & $\begin{array}{l}\text { Value } \\
\text { propositions }\end{array}$ & Channels & $\begin{array}{l}\text { Customer } \\
\text { relationships }\end{array}$ & $\begin{array}{l}\text { Revenue } \\
\text { streams }\end{array}$ & $\begin{array}{l}\text { Key } \\
\text { resources }\end{array}$ & $\begin{array}{l}\text { Key } \\
\text { activities }\end{array}$ & $\begin{array}{l}\text { Key } \\
\text { partnerships }\end{array}$ & $\begin{array}{l}\text { Cost } \\
\text { structure }\end{array}$ \\
\hline Authors & & & & & & & & & \\
\hline $\begin{array}{l}\text { C.M. DaSilva, P. Trkman, } \\
\text { K. Desouza\&tJ. Lindič [65] }\end{array}$ & & $\begin{array}{l}\text { Customer value } \\
\text { proposition }\end{array}$ & Value network & & Earning logic & $\begin{array}{l}\text { Resources and } \\
\text { capabilities }\end{array}$ & & & \\
\hline $\begin{array}{l}\text { L. Achtenhagen, L. } \\
\text { Melin\&L. Naldi [62] }\end{array}$ & & & & & & $\begin{array}{l}\text { Critical } \\
\text { capabilities }\end{array}$ & $\begin{array}{l}\text { Strategising } \\
\text { actions, } \\
\text { activities }\end{array}$ & & \\
\hline $\begin{array}{l}\text { J. Aspara, J.A. Lamberg, } \\
\text { A. Laukia\&t. Tikkanen } \\
\text { [66] }\end{array}$ & & & & $\begin{array}{l}\text { Business network } \\
\text { relationships }\end{array}$ & $\begin{array}{l}\text { Finance and } \\
\text { accounting }\end{array}$ & $\begin{array}{l}\text { Operations and } \\
\text { resources }\end{array}$ & & & $\begin{array}{l}\text { Strategy and } \\
\text { structure }\end{array}$ \\
\hline $\begin{array}{l}\text { M.W. Johnson, C.M. } \\
\text { Christensen\&H. } \\
\text { Kagermann [67] }\end{array}$ & & $\begin{array}{l}\text { Customer value } \\
\text { proposition }\end{array}$ & & & Profit formula & Key resources & Key processes & & \\
\hline $\begin{array}{l}\text { H. Chesbrough\&R.S. } \\
\text { Rosenbloom [51] }\end{array}$ & $\begin{array}{l}\text { Market } \\
\text { segment }\end{array}$ & $\begin{array}{l}\text { Value } \\
\text { proposition }\end{array}$ & $\begin{array}{l}\text { Structure of the } \\
\text { value chain }\end{array}$ & & $\begin{array}{l}\text { Revenue } \\
\text { mechanism(s), profit } \\
\text { potential }\end{array}$ & & & $\begin{array}{l}\text { Firm position } \\
\text { within a value } \\
\text { network }\end{array}$ & $\begin{array}{l}\text { Cost } \\
\text { structure }\end{array}$ \\
\hline B. Demil\&X. Lecocq [68] & & $\begin{array}{l}\text { Propositions for } \\
\text { value delivery }\end{array}$ & $\begin{array}{l}\text { Organisational } \\
\text { structure }\end{array}$ & & & $\begin{array}{l}\text { Resources and } \\
\text { competencies }\end{array}$ & & & \\
\hline F. Günzel\&A.B. Holm [69] & & $\begin{array}{l}\text { Value } \\
\text { proposition }\end{array}$ & Value delivery & & Value capture & & $\begin{array}{l}\text { Value } \\
\text { creation }\end{array}$ & & \\
\hline D.J. Teece [70] & $\begin{array}{l}\text { Market } \\
\text { segment }\end{array}$ & $\begin{array}{l}\text { Value } \\
\text { mechanisms }\end{array}$ & & & Revenue streams & & & & \\
\hline $\begin{array}{l}\text { M.N. Cortimiglia, A. } \\
\text { Ghezzi\&A.G. Frank [71] }\end{array}$ & & $\begin{array}{l}\text { Value } \\
\text { proposition }\end{array}$ & Value delivery & & Value appropriation & & $\begin{array}{l}\text { Value } \\
\text { creation }\end{array}$ & Value networking & \\
\hline M.W. Johnson [72] & & $\begin{array}{l}\text { Customer value } \\
\text { proposition }\end{array}$ & & & Profit formula & Key resources & Key processes & & \\
\hline
\end{tabular}


S. Djelassi\&l. Decoopman [81] explicitly describe the open business model as a type of business model with a direct association with open innovation. A.B. Holm, F. Gunzel\&J.P. Ulhoi [11] took a slightly different approach by looking at the implicit duality of openness: openness to innovations, and openness of business models. Either explicitly or implicitly, the universally accepted view is that the open business model is a way of connecting strategic decisions with value creation to customers (business or managerial strategy), through the mechanism employed to capture it (innovation strategy), and converting it to profit (financial or economic strategy). Some prominent scholars have called for open business model research to be diverted from the current line of argument (as noted between the American and the European schools of thought), and rather be viewed as a continuum of practices [e.g. 9, 58].

\section{RESULTS AND DISCUSSION}

Using the selection criteria described at the end of the methodology section, articles were imported into the EndNote reference management software, and quality checks - such as duplicate elimination and full-text search - were undertaken. Some 120 articles were then selected for review (see Table 4).

Table 4: Article selection for review, grouped by keyword and database

\begin{tabular}{|c|c|c|c|c|c|c|c|c|}
\hline \multirow[t]{2}{*}{ Keyword } & \multirow[t]{2}{*}{ Database } & \multirow{2}{*}{$\begin{array}{l}\text { Initial search } \\
\text { output }\end{array}$} & \multicolumn{5}{|c|}{ Methodological screening } & \multirow{2}{*}{$\begin{array}{l}\text { Articles selected } \\
\text { for review }\end{array}$} \\
\hline & & & $a$ & $B$ & $\mathrm{Y}$ & $\delta$ & $\varepsilon$ & \\
\hline \multirow{4}{*}{$\begin{array}{l}\text { Open } \\
\text { innovation }\end{array}$} & EBSCOhost & 171 & 25 & 43 & $\mathrm{n} / \mathrm{a}$ & 55 & 33 & 15 \\
\hline & Scopus & 1433 & 18 & 241 & 0 & 1060 & 92 & 22 \\
\hline & Web of Science & 304 & $\mathrm{n} / \mathrm{a}$ & 68 & 1 & 186 & 24 & 25 \\
\hline & Total & 1908 & 43 & 352 & 1 & 1301 & 149 & 62 \\
\hline \multirow[t]{4}{*}{ Business model } & EBSCOhost & 428 & 222 & 78 & $\mathrm{n} / \mathrm{a}$ & 112 & 10 & 6 \\
\hline & Scopus & 4071 & 101 & 993 & 23 & 2798 & 136 & 20 \\
\hline & Web of Science & 398 & $\mathrm{n} / \mathrm{a}$ & 140 & 7 & 231 & 5 & 15 \\
\hline & Total & 4897 & 323 & 1211 & 30 & 3141 & 151 & 41 \\
\hline \multirow{4}{*}{$\begin{array}{l}\text { Open business } \\
\text { model }\end{array}$} & EBSCOhost & 4 & 0 & 0 & $\mathrm{n} / \mathrm{a}$ & 1 & 1 & 2 \\
\hline & Scopus & 21 & 0 & 6 & 3 & 0 & 4 & 8 \\
\hline & Web of Science & 30 & $\mathrm{n} / \mathrm{a}$ & 14 & 8 & $\mathrm{n} / \mathrm{a}$ & 1 & 7 \\
\hline & Total & 55 & 0 & 20 & 11 & 1 & 6 & 17 \\
\hline \multicolumn{2}{|l|}{ Grand total } & 6860 & 366 & 1583 & 42 & 4443 & 306 & 120 \\
\hline
\end{tabular}

See Table 5 below for the list of journals found to be most popular across the three domains, shown by the number of articles and their proportion of the total. It can be noted from Table 5 that five journals together accounted for over half of the total number of articles.

Table 5: Journals most prolific in the open innovation, business model, and open business model domains

\begin{tabular}{|l|c|c|}
\hline Journal & Number of papers & Percentage of total \\
\hline Long Range Planning & 18 & 15 \\
\hline Technology Analysis and Strategic Management & 17 & 14.2 \\
\hline Research and Development Management & 16 & 13.3 \\
\hline Research-Technology Management & 10 & 8.3 \\
\hline Technovation & 10 & 8.3 \\
\hline International Journal of Technology Management & 8 & 6.7 \\
\hline International Journal of Innovation Management & 8 & 6.7 \\
\hline
\end{tabular}




\begin{tabular}{|l|c|c|}
\hline Journal & Number of papers & Percentage of total \\
\hline European Journal of Innovation Management & 6 & 5 \\
\hline Strategic Entrepreneurship Journal & 5 & 4.2 \\
\hline Management Decision & 4 & 3.3 \\
\hline Industrial Marketing Management & 3 & 2.5 \\
\hline International Entrepreneurship and Management Journal & 2 & 1.7 \\
\hline Other journals (one each) & 13 & 10.8 \\
\hline
\end{tabular}

A geographic perspective was also taken, which indicated that of the 120 articles identified, the largest number of authors came from the USA, followed by Germany and Spain. A number of countries were represented by only one author, while none of the articles reviewed had any author from Africa. Figure 4 depicts the number of articles reviewed in relation to the country of domicile of the author(s). The proportion of the number of articles per country relative to the total is also given as a percentage.

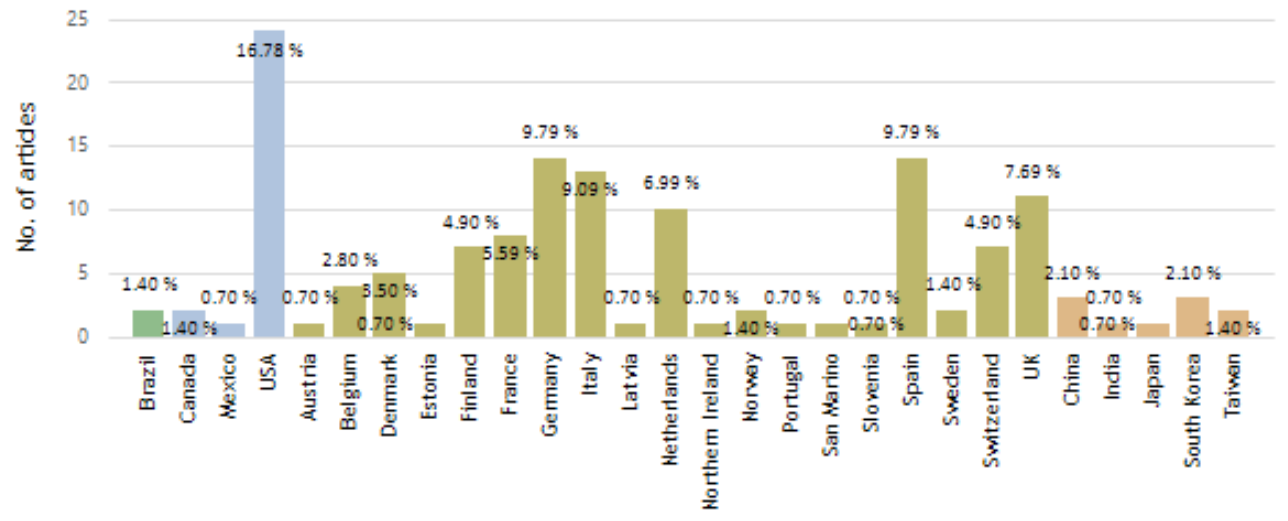

Country of author(s) domicile

Figure 4: The number and proportion of articles by country of author domicile

As can be deduced from Figures 4 and 5, European countries had the largest representation in the articles reviewed. Asia was represented by five countries, each with between one and three articles. No African country is represented in the review; but it is interesting to note that three of South Africa's partners in the association of five major emerging national economies: Brazil, Russia, India, China and South Africa (BRICS) are represented. The three are Brazil, China and India.

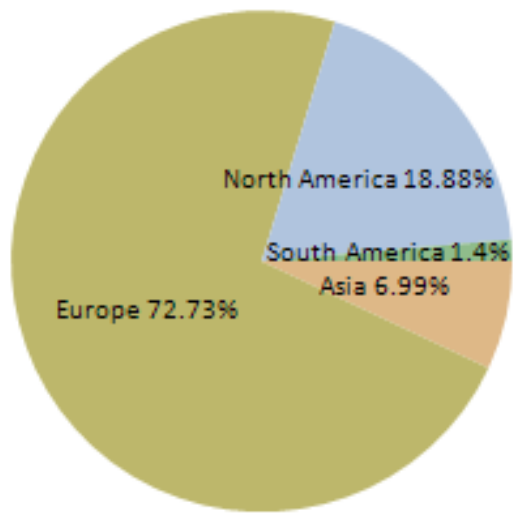

Figure 5: Proportion of articles by continent of the domicile of the author(s)

The review was further structured into the open business model's main functions and objectives, as well as elements of an archetype framework, as discussed in the next section. A crucial premise that 
underpins the discussion that follows is the inherent need for the adaptation and renewal that underlies the business model, which is often represented in a systemic form as a collection of elements and their underlying relations. Like any living system, these elements and their relations give business models their own life cycle [60]. S.G. Winter\&G. Szulanski [82] argue that "the formula or business model, far from being a quantum of information that is revealed in a flash, is typically a complex set of interdependent routines that is discovered, adjusted and fine-tuned by 'doing'".

\subsection{The open business model as a bridging construct between innovation and organisational performance}

One of the biggest challenges currently facing the open innovation community is proving the actual benefit of openness, especially due to a lack of value measurement instruments [56]. Some companies pursue openness simply because it is a popular phenomenon at present, not because of forecast revenue streams. The (open) business model has the difficult responsibility of defining the mechanism for these revenue streams.

The literature noted multiple conflicts, with one prominent conflict in the link between dynamism and organisational success. The majority of the relevant studies found that successful organisations are dynamic in undertaking inbound and outbound, as well as short- and long-term, targets [83]. However, others such as Wei, Zhao and Zhang [85] argue against this notion. Some older studies also indicated their failure to link dynamism and firm performance [e.g. 84]. A similar contradiction is noted in studies that look at only one of the two dimensions, with the majority of studies finding that there is a positive relationship between inbound open innovation activities and innovation outcomes [e.g. 85, 86]; other studies [e.g. 43, 87] show that the effects of this relationship can also be negative.

D.J. Teece [70]'s study [70], however, revealed that the business model and enterprise performance relationship are not entirely conclusive; rather, they are context-specific. D.J. Teece [70] found that a great business model does not necessarily lead to better enterprise performance. $V$. Van de Vrande, J.P.J. de Jong, W. Vanhaverbeke\&M. de Rochemont [48] and U. Lichtenthaler [88] found that SMEs predominantly embark on openness to keep up with their competition or to avoid being pushed out of business. On the other hand, large corporations embark on openness to achieve an iron grip on markets. The literature has yet to show how the benefits map out in collaboration engagements.

The previous generation of strategy scholars argue that survival (a basic achievement that organisations seek before expecting to attain performance) depends on exercising strategic leadership; building dynamic core competencies through both in-house development and strategic partnerships; focusing on and developing human capital; effectively using technologies; and implementing new organisational structures and culture [89]. Further exploration of these could establish precise mapping between innovation and performance.

\subsection{Adaptation mechanisms related to environmental change}

Openness is generally reflected as a feasible bridge for organisational performance and as an adaptation mechanism for organisations that face environmental change. These general benefits include numerous formal and informal, direct and indirect, planned and derived, and primary and secondary benefits. Despite these benefits and the general dichotomy in the literature, it is conceded that openness can be excessive and that there is a risk of alliance partners appropriating innovation output to other parties not intended by the focal organisation [90]. Therefore, organisations seem to use formal contracts to organise their open innovation activities with specific partner organisations, rather than engaging in open disclosure [91]. Whatever the need for it, the literature again shows that contracting may not be sufficient for the effective governance of open innovation projects, but that good social relations (non-contractual) may be invaluable [92].

B. Elvesaeter, A.J. Berre, H. de Man\&M.S. Li [93] noted a movement towards a broader concept of value creation beyond economic value, which includes defining new measurements for success beyond economic performance. This movement predicts that enterprises of the future will be better off embracing the different perspectives of sustainability, as the environment continuously changes. Customer demands and regulations that target specific environmental and social practices that are undertaken by organisations will increasingly have economic consequences [93], as would advances in information and communication technologies [94], globalisation, reduced product lifecycles, 
increased customer demands for new and reliable products and services, and reduced barriers of entry for new competitors [95].

\subsection{Elements of an archetype framework of the open business model}

Multiple studies tend to recommend openness [e.g. 42, 74, 96]. However, there is no explicit directive about what managers have to deal with or how they should overcome the challenges brought about by openness. A strategic and operating management model, or rather a toolkit, is necessary. In more progressive organisations, business model change is not necessarily motivated by poor organisational performance, but can even occur while the organisation is thriving [97]. Such proactiveness could anticipate a decline in performance, or offer foresight into better returns with a new configuration. The development of new organisational routines, such as evaluation procedures and metrics of performance [74], could be considered to be the foundation of business model archetypes.

Furthermore, the literature generally agrees that enterprises, when operating under uncertainty, should experiment with a range of business models [98]. Through experimentation, the initial value proposition evolves into a viable business model by using a series of trial-and-error changes that are pursued along various dimensions [99].

An open business model archetype does not need to digress from existing knowledge. Only a new configuration of existing elements is necessary. Table 6 indicates the attributes that should be considered in an archetype framework of open business models.

Table 6: Attributes of proposed framework and references

\begin{tabular}{|l|l|}
\hline Feature of proposed framework & Authors \\
\hline $\begin{array}{l}\text { Iteration (consists of decision gates and } \\
\text { feedback loops) }\end{array}$ & $\begin{array}{l}\text { K. Frankenberger, T. Weiblen, M. Csik\&O. Gassmann [13], J. } \\
\text { Hagberg\&H. Kjellberg [100] }\end{array}$ \\
\hline Value calculation mechanism & D.J. Teece [70], K. Storbacka [101] \\
\hline Strategic agility/flexibility & Y.L. Doz\&M. Kosonen [97], H. Chesbrough [102] \\
\hline $\begin{array}{l}\text { Managerial assumptions } \\
\text { (effort on proximity to fact) }\end{array}$ & $\begin{array}{l}\text { H. Chesbrough\&R.S. Rosenbloom [103], K. Mason\&M. Spring } \\
\text { [104] }\end{array}$ \\
\hline (Organisational) dynamic capability & $\begin{array}{l}\text { D.J. Teece [70], K. Mason\&S. Leek [105] } \\
\text { Boundary-spanning concept }\end{array}$ \\
$\begin{array}{l}\text { C. Zott, R. Amit\&M. Massa [4], A.B. Holm, F. Gunzel\&J.P. } \\
\text { Ulhoi [11] }\end{array}$ \\
\hline
\end{tabular}

\section{CONCLUSIONS}

The three main findings of this review are the following:

1. Open business model studies are almost exclusively American and European. Studies on or in Africa could not be detected using the selection criteria of this study.

2. Scholars have not reached a conclusion about comprehending the conception of the open business model. Literature that is more recent challenges and antagonises older, more established literature.

3. There is no archetype of the open business model. The requisite elements are known - the central one being value - but the need for competitiveness and the ever-changing business environment have made the open business model immensely relevant in this era.

Most of the existing research in the field focuses on the potential benefits of openness rather than addressing the disadvantages. This could lead to a biased literature, as noted by L. Dahlander\&D.M. Gann [58].

Based on numerous scholars' predictions of continuing environmental change, the entire economic paradigm for business may change in the long run, leading to a fundamental transformation of the understanding of, and approach to, business models. The usefulness of a business model can be measured when it has been implemented and the consequences of this implementation have been revealed (eventual success or failure). Assessment methods that allow the qualification of new theoretical business models before their implementation, in order to choose, configure, or define appropriate business models prior to application, are necessary. In fact, the lack of ex-ante assessment methods often turns business model selection into a purely intuitive choice that is not based on rational criteria. 


\section{REFERENCES}

[1] Meads, D., "Digital skills part of SA's future," 2017/04/24. Accessed on: 2017/07/19Available: http://www.iol.co.za/business-report/opinion/digital-skills-part-of-sas-future-8791349

[2] Treasury, N., "Budget Review 2017," National Treasury Republic of South Africa2017, Available: http://www.treasury.gov.za/documents/national\%20budget/2017/review/FullBR.pdf.

[3] George, G. \& Bock, A. J., "The business model in practice and its implications for entrepreneurship research," Entrepreneurship Theory and Practice, vol. 35, pp. 83-111, 2011.

[4] Zott, C., Amit, R. \& Massa, M., "The Business Model: Recent Developments and Future Research," Journal of Management, vol. 37, pp. 1019-1042, 2011.

[5] Osterwalder, A. \& Pigneur, Y., Business Model Generation - A Handbook for Visionaries, Game Changers and Challengers. Hoboken, New Jersey: John Wiley and Sons, Inc., 2010.

[6] Chesbrough, H., "Why Bad Things Happen To Good Technology," Wall Street Journal - Eastern Edition, Article vol. 249, no. 99, p. R11, 2007.

[7] Davey, S. M., Brennan, M., Meenan, B. J. \& McAdam, R., "A framework to manage the innovation strategies of new technology based firms," in Proceedings of the 1st International Technology Management Conference, ITMC 2011, 2011, pp. 1007-1013.

[8] Purdy, M., Robinson, M. C. \& Wei, K., "Three new business models for "the open firm"," Strategy \& Leadership, vol. 40, no. 6, pp. 36-41, 2012.

[9] Sandulli, F. \& Chesbrough, H., "The two faces of open business models," Research Paper Series (RPS), Available: http://dx.doi.org/10.2139/ssrn.1325682

[10] Sheets, R. G. \& Crawford, S., "Harnessing the Power of Information Technology: Open Business Models in Higher Education," Educause Review, vol. 47, no. 2, p. n2, 2012.

[11] Holm, A. B., Gunzel, F. \& Ulhoi, J. P., "Openness in innovation and business models: lessons from the newspaper industry," (in English), International Journal of Technology Management, Article vol. 61, no. 34, pp. 324-348, 2013.

[12] Romero, D. \& Molina, A., "Collaborative networked organisations and customer communities: value cocreation and co-innovation in the networking era," Production Planning \& Control, vol. 22, no. 5-6, pp. 447-472, 2011.

[13] Frankenberger, K., Weiblen, T., Csik, M. \& Gassmann, O., "The 4l-framework of business model innovation: a structured view on process phases and challenges," International Journal of Product Development, vol. 18, no. 3/4, pp. 249-273, 2013.

[14] Berglund, H. \& Sandström, C., "Business model innovation from an open systems perspective: Structural challenges and managerial solutions," (in English), International Journal of Product Development, vol. 18, no. 3-4, pp. 274-285, 2013.

[15] Storbacka, K., Frow, P., Nenonen, S. \& Payne, A., "Designing Business Models for Value Co-Creation," vol. 9, Special Issue - Toward a Better Understanding of the Role of Value in Markets and Marketing, S. L. Vargo\&R. F. Lusch, Eds.: Emerald Group Publishing Limited, 2012, pp. 51-78. [Online]. Available.

[16] Denyer, D. \& Tranfield, D., D. A. Buchanan\&A. Bryman, Eds. Producing a systematic review (The SAGE Handbook of Organizational Research Methods). Thousand Oaks, CA: SAGE Publishers, 2009.

[17] Aminoff, A., Kaipia, R., Matti, P., Kari, T., Mervi, V. \& Makkonen, M., "Managing supplier innovations A systematic literature review," in 24th Annual IPSERA Conference, Amsterdam, Netherlands, 2015.

[18] Jalonen, H., "The Uncertainty of Innovation: A Systematic Review of the Literature," Journal of Management Research, vol. 4, no. 1, pp. 1-47, 2012.

[19] Kitchenham, B. A. \& Charters, S., "Guidelines for performing Systematic Literature Reviews in Software Engineering," in "EBSE Technical Report," Keele University and University of Durham2007.

[20] Crossan, M. M. \& Apaydin, M., "A multi-dimensional framework of organizational innovation: A systematic review of the literature," Journal of management studies, vol. 47, no. 6, pp. 1154-1191, 2010.

[21] Velamuri, V. K., "Business Model Innovation Opportunities for the Biopharmaceutical Industry: A Systematic Review," Journal of Commercial Biotechnology, vol. 22, no. 3, pp. 19-63, 2016.

[22] Asher, A. D., Duke, L. M. \& Wilson, S., "Paths of Discovery: Comparing the Search Effectiveness of EBSCO Discovery Service, Summon, Google Scholar, and Conventional Library Resources.," College and Research Libraries, vol. 74, no. 5, pp. 464-488, 2012.

[23] Falagas, M. E., Pitsouni, E. I., Malietzis, G. A. \& Pappas, G., "Comparison of PubMed, Scopus, web of science, and Google scholar: strengths and weaknesses," The FASEB journal, vol. 22, no. 2, pp. 338-342, 2008.

[24] Aghaei Chadegani, A., Salehi, H., Yunus, M. M., Farhadi, H., Fooladi, M., Farhadi, M. \& Ale Ebrahim, N., "A comparison between two main academic literature collections: Web of Science and Scopus databases," Asian Social Science, vol. 9, no. 5, pp. 18-26, 2013. 27/04/2013

[25] Konkiel, S., "4 reasons why Google Scholar isn't as great as you think it is," ed, 2014.

[26] Walters, W. H., "Comparative Recall and Precision of Simple and Expert Searches in Google Scholar and Eight Other Databases," portal: Libraries \& the Academy, Article vol. 11, no. 4, pp. 971-1006, 2011.

[27] Schneider, S. \& Spieth, P., "Business model innovation: Towards an integrated future research agenda," (in English), International Journal of Innovation Management, Conference Paper vol. 17, no. 1, pp. 1-34, 2013, Art. no. 1340001.

[28] Tranfield, D., Denyer, D. \& Smart, P., "Towards a methodology for developing evidence-informed management knowledge by means of systematic review," British journal of management, vol. 14, no. 3, pp. 207-222, 2003. 
[29] Ganann, R., Ciliska, D. \& Thomas, H., "Methodology Expediting systematic reviews: methods and implications of rapid reviews," Implementation Science, vol. 5, no. 56, pp. 1-10, 2010.

[30] Pittaway, L., Robertson, M., Munir, K., Denyer, D. \& Neely, A., "Networking and innovation: a systematic review of the evidence," International journal of management reviews, vol. 5, no. 3-4, pp. 137-168, 2004.

[31] Coombes, P. H. \& Nicholson, J. D., "Business models and their relationship with marketing: A systematic literature review," Industrial Marketing Management, vol. 42, no. 5, pp. 656-664, 7// 2013.

[32] Chesbrough, H., "Open innovation and the business model: Implications for industrial research," in $A I C h E$ and ACS Management Conference 2003: Innovation Across Boundaries, Amelia Island, FL, 2003, pp. 119. 148.

[33] Chesbrough, H. W., Open innovation: The new imperative for creating and profiting from technology. Harvard Business Press, 2003.

[34] Galbraith, B. \& McAdam, R., "The promise and problem with open innovation," Technology Analysis \& Strategic Management, Article vol. 23, no. 1, pp. 1-6, 2011.

[35] Chesbrough, H., Vanhaverbeke, W. \& West, J., Open innovation: Researching a new paradigm. Oxford University Press on Demand, 2006.

[36] Chesbrough, H. W., "The era of open innovation," MIT Sloan Management Review, vol. 44, no. 3, pp. 3541, Spr 2003.

[37] Bianchi, M., Cavaliere, A., Chiaroni, D., Frattini, F. \& Chiesa, V., "Organisational modes for Open Innovation in the bio-pharmaceutical industry: An exploratory analysis," Technovation, vol. 31, no. 1, pp. 22-33, Jan 2011.

[38] Enkel, E., Gassmann, O. \& Chesbrough, H., "Open R\&D and open innovation: exploring the phenomenon," $R$ \& $D$ Management, vol. 39, no. 4, pp. 311-316, Sep 2009.

[39] Chiaroni, D., Chiesa, V. \& Frattini, F., "Unravelling the process from Closed to Open Innovation: evidence from mature, asset-intensive industries," $R$ \& $D$ Management, vol. 40, no. 3, pp. 222-245, Jun 2010.

[40] Tsai, K.-H. \& Wang, J.-C., "External technology sourcing and innovation performance in LMT sectors: An analysis based on the Taiwanese Technological Innovation Survey," Research Policy, vol. 38, no. 3, pp. 518526, 2009.

[41] Gassmann, O., "Opening up the innovation process: towards an agenda," R\&D Management, vol. 36, no. 3, pp. 223-228, 2006.

[42] Burcharth, A. L. D. A., Knudsen, M. P. \& Søndergaard, H. A., "Neither invented nor shared here: The impact and management of attitudes for the adoption of open innovation practices," Technovation, Article vol. 34, no. 3, pp. 149-161, 2014.

[43] Laursen, K. \& Salter, A., "Open for innovation: The role of openness in explaining innovative performance among UK manufacturing firms," Strategic Management Journal, vol. 27, pp. 131-150, 2006.

[44] Benson, D. \& Ziedonis, R. H., "Corporate venture capital as a window on new technologies: Implications for the performance of corporate investors when acquiring startups," Organization Science, vol. 20, no. 2 , pp. 329-351, 2009.

[45] Vanhaverbeke, W., Vermeersch, I. \& De Zutter, S., "Open innovation in SMEs: How can small companies and start-ups benefit from open innovation strategies?," Brussels, Belgium9078858885, 03/2012 2012, Available: http://hdl.handle.net/1942/13758.

[46] Holzmann, T., Sailer, K. \& Katzy, B. R., "Matchmaking as multi-sided market for open innovation," Technology Analysis \& Strategic Management, Article vol. 26, no. 6, pp. 601-615, 2014.

[47] Spithoven, A., Clarysse, B. \& Knockaert, M., "Building absorptive capacity to organise inbound open innovation in traditional industries," Technovation, vol. 30, no. 2, pp. 130-141, 2010.

[48] Van de Vrande, V., de Jong, J. P. J., Vanhaverbeke, W. \& de Rochemont, M., "Open innovation in SMEs: Trends, motives and management challenges," Technovation, Article vol. 29, no. 6-7, pp. 423-437, 2009.

[49] Van Der Meer, H., "Open Innovation - The Dutch Treat: Challenges in Thinking in Business Models," Creativity and Innovation Management, vol. 16, no. 2, pp. 192-202, 2007.

[50] Harland, P. E. \& Nienaber, A.-M., "Solving the matchmaking dilemma between companies and external idea contributors," Technology Analysis \& Strategic Management, vol. 26, no. 6, pp. 639-653, Jul 2014.

[51] Chesbrough, H. \& Rosenbloom, R. S., "The role of the business model in capturing value from innovation: evidence from Xerox Corporation's technology spin-off companies," Industrial and Corporate Change, vol. 11, no. 3, pp. 529-555, Jun 2002.

[52] Chesbrough, H. \& Brunswicker, S., "A Fad or a Phenomenon? The Adoption of Open Innovation Practices in Large Firms," Research-Technology Management, vol. 57, no. 2, pp. 16-25, Mar-Apr 2014.

[53] Lichtenthaler, U. \& Ernst, H., "External technology commercialization in large firms: results of a quantitative benchmarking study," R\&D Management, vol. 37, no. 5, pp. 383-397, 2007.

[54] Lichtenthaler, U. \& Ernst, H., "Opening up the innovation process: the role of technology aggressiveness," R\&D Management, vol. 39, no. 1, pp. 38-54, 2009.

[55] Wynarczyk, P., Piperopoulos, P. \& McAdam, M., "Open innovation in small and medium-sized enterprises: An overview," International Small Business Journal, vol. 31, no. 3, pp. 240-255, May 2013.

[56] Gassmann, O., Enkel, E. \& Chesbrough, H., "The future of open innovation," $R$ \& $D$ Management, vol. 40, no. 3, pp. 213-221, Jun 2010.

[57] Trott, P. \& Hartmann, D., "Why 'open innovation' is old wine in new bottles," International Journal of Innovation Management, Conference Paper vol. 13, no. 4, pp. 715-736, 2009.

[58] Dahlander, L. \& Gann, D. M., "How open is innovation?," Research Policy, vol. 39, no. 6, pp. 699-709, 2010.

[59] Lazzarotti, V. \& Manzini, R., "Different modes of open innovation: A theoretical framework and an empirical study," International Journal of Innovation Management, Conference Paper vol. 13, no. 4, pp. 615-636, 2009. 
[60] Arbussa, A., Bikfalvi, A. \& Marques, P., "Strategic agility-driven business model renewal: the case of an SME," Management Decision, vol. 55, no. 2, pp. 271-293, 2017.

[61] Afuah, A., "Does a focal firm's technology entry timing depend on the impact of the technology on coopetitors?," Research Policy, vol. 33, no. 8, pp. 1231-1246, 2004.

[62] Achtenhagen, L., Melin, L. \& Naldi, L., "Dynamics of business models - strategizing, critical capabilities and activities for sustained value creation," (in English), Long Range Planning, Article vol. 46, no. 6, pp. 427-442, 2013.

[63] Baden-Fuller, C. \& Morgan, M. S., "Business models as models," (in English), Long Range Planning, Article vol. 43, no. 2-3, pp. 156-171, 2010.

[64] Wirtz, B. W., Pistoia, A., Ullrich, S. \& Göttel, V., "Business Models: Origin, Development and Future Research Perspectives," (in English), Long Range Planning, Article vol. 49, no. 1, pp. 36-54, 2016.

[65] DaSilva, C. M., Trkman, P., Desouza, K. \& Lindič, J., "Disruptive technologies: a business model perspective on cloud computing," Technology Analysis \& Strategic Management, Article vol. 25, no. 10, pp. 1161-1173, 2013.

[66] Aspara, J., Lamberg, J. A., Laukia, A. \& Tikkanen, H., "Strategic management of business model transformation: lessons from Nokia," Management Decision, vol. 49, no. 3-4, pp. 622-647, 2011.

[67] Johnson, M. W., Christensen, C. M. \& Kagermann, H., "Reinventing Your Business Model.," Harvard Business Review, vol. 86, no. 12, pp. 1-12, 2008.

[68] Demil, B. \& Lecocq, X., "Business model evolution: In search of dynamic consistency," (in English), Long Range Planning, Article vol. 43, no. 2-3, pp. 227-246, 2010.

[69] Guinzel, F. \& Holm, A. B., "One Size Does Not Fit All - Understanding the Front-End and BackEnd of Business Model Innovation," International Journal of Innovation Management vol. 17, no. 1, pp. 1-34, 2013.

[70] Teece, D. J., "Business models, business strategy and innovation," (in English), Long Range Planning, Article vol. 43, no. 2-3, pp. 172-194, 2010.

[71] Cortimiglia, M. N., Ghezzi, A. \& Frank, A. G., "Business model innovation and strategy making nexus: evidence from a cross-industry mixed-methods study," $R$ \& $D$ Management, vol. 46, no. 3, pp. 414-432, Jun 2016.

[72] Johnson, M. W., Seizing the white space: Business model innovation for growth and renewal. Boston, MA: Harvard Business Press, 2010.

[73] Chesbrough, H. \& Schwartz, K., "Innovating business models with co-development partnerships," (in English), Research Technology Management, vol. 50, no. 1, pp. 55-59, 2007.

[74] Chesbrough, H., Open Business Models: How to thrive in the New Innovation Landscape. Boston: Harvard Business School Press, 2006.

[75] Frankenberger, K., Weiblen, T. \& Gassmann, O., "Network configuration, customer centricity, and performance of open business models: A solution provider perspective," Industrial Marketing Management, Article vol. 42, no. 5, pp. 671-682, 2013.

[76] Heikkila, M. \& Heikkila, J., "Collaborative Business Model Innovation Process for Networked Services," in Co-Created Effective, Agile, and Trusted Eservices, vol. 155, J. Jarvelainen, H. Li, A. M. Tuikka\&T. Kuusela, Eds. (Lecture Notes in Business Information Processing, 2013, pp. 133-147.

[77] Chesbrough, H., "Open Innovation Where We've Been and Where We're Going," Research-Technology Management, vol. 55, no. 4, pp. 20-27, Jul-Aug 2012.

[78] Zott, C. \& Amit, R., "Business Model Design: An Activity System Perspective," Long Range Planning, vol. 43, no. 2-3, pp. 216-226, 2010.

[79] Bouwman, H., de Vos, H. \& Haaker, T., Mobile service innovation and business models. Heidelberg, Germany: Springer Science \& Business Media, 2008.

[80] Weiblen, T., "The Open Business Model: Understanding an Emerging Concept," Journal of Multi Business Model Innovation and Technology, vol. 2, no. 1, pp. 35-66, 2014.

[81] Djelassi, S. \& Decoopman, I., "Customers' participation in product development through crowdsourcing: Issues and implications," (in English), Industrial Marketing Management, Article vol. 42, no. 5, pp. 683692, Jul 2013.

[82] Winter, S. G. \& Szulanski, G., "Replication as strategy," Organization science, vol. 12, no. 6, pp. 730-743, 2001.

[83] Hu, B. \& Chen, W., "Business model ambidexterity and technological innovation performance: evidence from China," Technology Analysis \& Strategic Management, Article vol. 28, no. 5, pp. 583-600, 2016.

[84] Menguc, B. \& Auh, S., "The asymmetric moderating role of market orientation on the ambidexterity-firm performance relationship for prospectors and defenders," Industrial Marketing Management, vol. 37, no. 4, pp. 455-470, 2008.

[85] Faems, D., Van Looy, B. \& Debackere, K., "Interorganizational collaboration and innovation: Toward a portfolio approach," Journal of product innovation management, vol. 22, no. 3, pp. 238-250, 2005.

[86] Parida, V., Westerberg, M. \& Frishammar, J., "Inbound Open Innovation Activities in High-Tech SMEs: The Impact on Innovation Performance," Journal of Small Business Management, vol. 50, no. 2, pp. 283-309, Apr 2012.

[87] Torkkeli, M. T., Kock, C. J. \& Salmi, P. A., "The "Open Innovation” paradigm: A contingency perspective," Journal of Industrial Engineering and Management, vol. 2, no. 1, pp. 176-207, 2009.

[88] Lichtenthaler, U., "Open innovation in practice: An analysis of strategic approaches to technology transactions," IEEE Transactions on Engineering Management, Article vol. 55, no. 1, pp. 148-157, 2008.

[89] Hitt, M., Harrison, J., Ireland, R. D. \& Best, A., "Attributes of successful and unsuccessful acquisitions of US firms," British Journal of Management, vol. 9, no. 2, pp. 91-114, 1998. 
[90] Chesbrough, H. \& Crowther, A. K., "Beyond high tech: early adopters of open innovation in other industries," $R$ \& $D$ Management, vol. 36, no. 3, pp. 229-236, Jun 2006.

[91] Hagedoorn, J. \& Zobel, A. K., "The role of contracts and intellectual property rights in open innovation," Technology Analysis and Strategic Management, Article vol. 27, no. 9, pp. 1050-1067, 2015.

[92] Granstrand, O. \& Holgersson, M., "The Challenge of Closing Open Innovation The Intellectual Property Disassembly Problem," Research-Technology Management, vol. 57, no. 5, pp. 19-25, Sep-Oct 2014.

[93] Elvesaeter, B., Berre, A. J., de Man, H. \& Li, M. S., Networked Enterprise Transformation and Resource Management in Future Internet Enabled Innovation Clouds (Enterprise Interoperability Iv: Making the Internet of the Future for the Future of Enterprise). Godalming: Springer-Verlag London Ltd, 2010, pp. 313322.

[94] McGrath, R. G., "Business models: A discovery driven approach," Long Range Planning, vol. 43, pp. 247261, 2010.

[95] Jagoda, K., Maheshwari, B. \& Gutowski, G., "Deer creek land development (DCLD): Open business model approach to sustaining competitive advantage," International Journal of Commerce and Management, Article vol. 22, no. 2, pp. 133-144, 2012.

[96] Enkel, E., Bell, J. \& Hogenkamp, H., "Open innovation maturity framework," International Journal of Innovation Management, Conference Paper vol. 15, no. 6, pp. 1161-1189, 2011.

[97] Doz, Y. L. \& Kosonen, M., "Embedding strategic agility: A leadership agenda for accelerating business model renewal," (in English), Long Range Planning, Article vol. 43, no. 2-3, pp. 370-382, 2010.

[98] Andries, P., Debackere, K. \& Van Looy, B., "SIMULTANEOUS EXPERIMENTATION AS A LEARNING STRATEGY: BUSINESS MODEL DEVELOPMENT UNDER UNCERTAINTY," Strategic Entrepreneurship Journal, vol. 7, no. 4, pp. 288-310, Dec 2013.

[99] Nicholls-Nixon, C. L. \& Woo, C. U., "Technology sourcing and output of established firms in a regime of encompassing technological change," Strategic Management Journal, vol. 24, no. 7, pp. 651-666, 2003.

[100] Hagberg, J. \& Kjellberg, H., "Who performs marketing? Dimensions of agential variation in market practice," Industrial Marketing Management, vol. 39, no. 6, pp. 1028-1037, 2010.

[101] Storbacka, K., "A solution business model: Capabilities and management practices for integrated solutions," Industrial Marketing Management, vol. 40, no. 5, pp. 699-711, 7// 2011.

[102] Chesbrough, H., "Business model innovation: Opportunities and barriers," (in English), Long Range Planning, Article vol. 43, no. 2-3, pp. 354-363, 2010.

[103] Chesbrough, H. \& Rosenbloom, R. S., "The role of the business model in capturing value from innovation: evidence from Xerox Corporation's technology spin-off companies," Industrial and Corporate Change, vol. 11, no. 3, pp. 529-555, 2002.

[104] Mason, K. \& Spring, M., "The sites and practices of business models," Industrial Marketing Management, vol. 40, no. 6, pp. 1032-1041, 8// 2011.

[105] Mason, K. \& Leek, S., "Learning to build a supply network: An exploration of dynamic business models," Journal of Management Studies, vol. 45, no. 4, pp. 774-799, 2008. 